\title{
KUTU PUTIH SINGKONG, PHENACOCCUS MANIHOTI MATILE-FERRERO (HEMIPTERA: PSEUDOCOCCIDAE): PERSEBARAN GEOGRAFI DI PULAU JAWA DAN RINTISAN PENGENDALIAN HAYATI
}

\author{
Budi Abduchalek ${ }^{1}$, Aunu Rauf ${ }^{2}$, \& Pudjianto $^{2}$ \\ ${ }^{1}$ Balai Pengkajian Teknologi Pertanian (BPTP) Kalimantan Barat \\ Jl. Budi Utomo No. 45, Siantan Hulu-Pontianak Utara 78241, Pontianak \\ ${ }^{2}$ Departemen Proteksi Tanaman, Fakultas Pertanian, Institut Pertanian Bogor \\ Kampus IPB-Dramaga, Bogor 16680, \\ E-mail: aunu@indo.net.id
}

\begin{abstract}
Cassava mealybug, Phenacoccus manihoti Matile-Ferrero (Hemiptera: Pseudococcidae): Geographic distribution in Java and initiation of biological control. Cassava mealybug, Phenacoccus manihoti Matile-Ferrero (Hemiptera: Psedococcidae), is a recently introduced pest in Indonesia. Parasitoid Anagyrus lopezi (De Santis) (Hymenoptera: Encyrtidae) was imported to control the pest. Studies were conducted to determine geographic distribution of $P$. manihoti throughout Java, and to evaluate the potential of the parasitoid as a biological control agent. Geographic distribution of the pest was determined through field survey, whereas evaluation of the parasitoid was studied through cage experiment and field release. Our survey revealed that the cassava mealybug has spread throughout Java. Heavy infestations caused shortened and distorted stems, complete defoliation, and stunted growth. In cages containing only mealybugs, all cassava plants (100\%) died after two months. Whereas in cages containing both mealybugs and three pairs of parasitoid, rate of parasitization was $25 \%$ and plant mortality $20 \%$. Parasitoids released in the field were able to survive, reproduce, and establish under Bogor climatic condition. These might indicate that parasitoid $A$. lopezi is a potential natural enemy to be used in biological control program of the cassava mealybug.
\end{abstract}

Key words: Anagyrus lopezi, biological control, cassava mealybug, parasitoid, Phenacoccus manihoti

\begin{abstract}
ABSTRAK
Kutu putih singkong, Phenacoccus manihoti Matile-Ferrero (Hemiptera: Pseudococcidae): Persebaran geografi di Pulau Jawa dan rintisan pengendalian hayati. Kutu putih singkong, Phenacoccus manihoti Matile-Ferrero (Hemiptera: Psedococcidae), merupakan hama baru di Indonesia. Parasitoid Anagyrus lopezi (De Santis) (Hymenoptera: Encyrtidae) didatangkan untuk mengendalikan hama tersebut. Penelitian bertujuan menentukan persebaran geografi P. manihoti di Pulau Jawa, serta mengkaji potensi A. lopezi sebagai agens pengendalian hayati. Persebaran geografi dilakukan melalui kegiatan survei lapangan, sedangkan evaluasi potensi parasitoid dilakukan melalui percobaan kurungan dan pelepasan di lapangan. Hasil penelitian menunjukkan kutu putih $P$. manihoti sudah tersebar luas di seluruh Pulau Jawa. Serangan berat menyebabkan batang memendek dan bengkok, gugur daun, dan pertumbuhan terhambat. Dalam kurungan yang hanya berisi kutu putih, seluruh tanaman singkong (100\%) mati setelah dua bulan. Dalam kurungan yang berisi kutu putih dan tiga pasang parasitoid, tingkat parasitisasi mencapai $25 \%$ dan kematian tanaman 20\%. Parasitoid yang dilepaskan di lapangan mampu berkembang biak dan menetap pada kondisi iklim di Bogor. Hal tersebut mengindikasikan bahwa parasitoid A. lopezi merupakan musuh alami yang potensial untuk digunakan dalam program pengendalian hayati kutu putih singkong.
\end{abstract}

Kata kunci: Anagyrus lopezi, kutu putih singkong, parasitoid, pengendalian hayati, Phenacoccus manihoti

\section{PENDAHULUAN}

Indonesia menduduki lima besar negara pengekspor singkong dunia dengan volume ekspor 19,9 juta ton, di bawah Nigeria (34,4 juta ton), Thailand (26,9 juta ton), dan Brasil (26,5 juta ton), tetapi di atas Kongo (15 juta ton) (Suherman, 2014). Dalam lima tahun terakhir ini produksi singkong Indonesia terancam oleh kehadiran hama baru yaitu kutu putih Phenacoccus manihoti Matile-Ferrero (Hemiptera: Pseudococcidae) (Rauf, 2014).

Kutu putih $P$. manihoti mulai menjadi perhatian dunia pada saat hama ini secara tidak sengaja terbawa masuk ke Afrika pada tahun 1970 (Nwanze et al., 1979), dan kemudian masuk ke Asia pada tahun 2009 (Parsa et al., 2012). Di Indonesia kutu P. manihoti pertama 
kali ditemukan di Bogor pada tahun 2010 (Muniappan et al., 2011). Serangan hama ini menyebabkan kehilangan hasil sekitar 82\% di Afrika (Nwanze, 1982) dan 40-50\% di Asia (Wyckhuys et al., 2014; Wardani, 2015).

Untuk mengendalikan hama baru ini, parasitoid Anagyrus lopezi (De Santis) (Hymenoptera: Encyrtidae) diintroduksikan dari Paraguay ke Afrika dan dilepaskan pertama kali di Nigeria pada tahun 1981 (Herren \& Lema, 1982). Dilaporkan bahwa kini parasitoid A. lopezi telah menyebar dan menetap di 25 negara di Afrika dan mampu menekan serangan kutu putih secara signifikan (Herren \& Neuenschwander, 1991). Norgaard (1988) memperkirakan nilai B/C ratio = 149: 1 dari kegiatan pengendalian hayati dengan introduksi parasitoid A. lopezi. Keberhasilan ini telah mendorong pemerintah Thailand untuk mendatangkan parasitoid dari Benin pada tahun 2011 (Lefroy, 2010). Seperti halnya yang terjadi di Afrika, introduksi parasitoid A. lopezi ke Thailand telah berhasil menekan kerusakan dan kerugian akibat serangan kutu putih $P$. manihoti (FAO, 2011). Berdasarkan keberhasilan di Afrika dan Thailand, pada awal tahun 2014 Indonesia mendatangkan parasitoid A. lopezi dari Thailand (Rauf, 2014).

Segera setelah didatangkan ke Indonesia, beberapa penelitian telah dilakukan di antaranya uji kekhususan inang (Karyani, 2015) dan biologi serta kesesuaian instar inang kutu P. manihoti bagi perkembangan parasitoid (Adriani, 2016). Penelitian berikutnya yang perlu dilakukan adalah mengevaluasi potensi parasitoid A. lopezi. Terdapat beberapa metode evaluasi, di antaranya adalah teknik eksklusi dan inklusi (Kiritani \& Dempster, 1973). Pada teknik eksklusi, populasi hama di alam dilindungi dari parasitoid atau predator dengan cara dikurung, dan kemudian dibandingkan dengan populasi yang tidak dikurung. Pada teknik inklusi, parasitoid atau predator dengan sengaja dimasukkan ke dalam kurungan, seperti yang dilakukan oleh Simmons \& Minkenberg (1994) dalam mengevaluasi Eretmocerus californicus Howard (Hymenoptera: Aphelinidae), sebagai parasitoid Bemisia argentifolii Bellows \& Perring (Hemiptera: Aleyrodidae). Teknik inklusi juga diterapkan oleh HengMoss et al. (1999) dalam mengevaluasi Rhopus nigroclavatus (Ashmead) (Hymenoptera: Encyrtidae), yang merupakan parasitoid kutu putih Tridiscus sporoboli (Cockerell) (Hemiptera: Pseudococcidae). Tahapan berikutnya dari introduksi musuh alami adalah pelepasan di lapangan. Untuk mengetahui apakah parasitoid yang dilepas mampu berkembang biak dan menetap di lapangan, perlu dilakukan pemantuan lanjutan seperti yang dilakukan oleh Herren et al. (1987) di
Afrika. Pada gilirannya nanti, pelepasan parasitoid perlu dilakukan di seluruh wilayah yang terserang kutu $P$. manihoti. Namun demikian, hingga saat ini belum diketahui secara pasti persebaran kutu P. manihoti ini di Indonesia, bahkan untuk lingkup Pulau Jawa sekalipun.

Berdasarkan pertimbangan tersebut di atas, penelitian ini bertujuan untuk menentukan persebaran geografi kutu putih $P$. manihoti dan kondisi serangan di Pulau Jawa, serta mengkaji potensi parasitoid $A$. lopezi sebagai agens pengendalian hayati kutu putih $P$. manihoti.

\section{METODE PENELITIAN}

Tempat dan Waktu. Survei dilaksanakan pada bulan Oktober 2014, yang meliputi wilayah di Jawa Barat, Jawa Tengah, Daerah Istimewa Yogyakarta, dan Jawa Timur. Posisi geografi setiap titik pengamatan dicatat menggunakan Garmin GPS MAP 62.

Kondisi Serangan P. manihoti di Pulau Jawa. Pada setiap lokasi dilakukan pengamatan terhadap tingkat serangan, kerapatan populasi, dan kondisi pertanaman secara umum. Tanaman singkong yang diamati meliputi tanaman yang tumbuh sebagai pagar, atau tanaman pekarangan, hingga perkebunan singkong yang luasannya sekitar 10 ha. Pengamatan dan penghitungan kutu putih dilakukan dengan cara membuka bagian pucuk tanaman muda atau membalik bagian bawah daun. Selain itu, bila ada kesempatan, dilakukan pula wawancara dengan petani singkong.

Percobaan Parasitisasi di dalam Kurungan. Percobaan dilaksanakan di dalam kurungan berkerangka kayu $(\mathrm{p}=60 \mathrm{~cm}, 1=50 \mathrm{~cm}, \mathrm{t}=120 \mathrm{~cm})$, yang bagian atas dan sisinya ditutupi kain kasa. Kedalam kurungan dimasukkan satu tanaman singkong berumur 3 minggu. Tanaman singkong kemudian diinokulasi dengan kutu putih instar-2 sebanyak 50 ekor, dan setelah itu dimasukkan parasitoid A. lopezi. Sebagai perlakuan adalah banyaknya parasitoid yang dimasukkan ke dalam kurungan, yaitu 1 pasang, 3 pasang, dan kontrol (tanpa parasitoid). Masing-masing perlakuan diulang 10 kali. Setelah 48 jam, seluruh kutu putih dan tanaman singkong dipindahkan pada kurungan lain, dan dipelihara sampai muncul imago parasitoid. Penghitungan parasitoid dilakukan pada 25 hari setelah inokulasi. Tingkat parasitisasi ditentukan berdasarkan banyaknya parasitoid yang muncul dibagi banyaknya kutu yang diinfestasikan. Banyaknya tanaman yang mati diamati pada hari ke25, 45, 60 setelah diinfestasi kutu putih. 
Percobaan Pelepasan Parasitoid di Lapangan. Percobaan dilakukan pada tiga pertanaman singkong milik petani di daerah Kedunghalang, Kabupaten Bogor. Pertanaman singkong yang dipilih adalah yang memiliki jarak tanam 1 x 1 m, jumlah tanaman minimum 2000 batang, serta berumur 4-5 bulan setelah tanam. Pada setiap pertanaman dilepas sebanyak 150 pasang parasitoid A. lopezi, yang kemudian diikuti dengan penyemprotan larutan madu $10 \%$ pada area 1-20 m dari titik pelepasan, sebagai sumber nutrisi imago parasitoid. Karena populasi kutu putih di lapangan sangat rendah, untuk menilai tingkat parasitisasi digunakan kutu putih hasil pembiakan di laboratorium sebagai sentinel atau perangkap. Kutu putih sentinel ini dipelihara pada bibit singkong yang ditumbuhkan pada wadah plastik $(\mathrm{d}=8$ $\mathrm{cm}, \mathrm{t}=11 \mathrm{~cm}$ ) yang setengahnya berisi air. Sebelum pelepasan parasitoid, bibit singkong yang mengandung kutu putih sentinel ini diikatkan pada tiang bambu $(\mathrm{t}=$ $150 \mathrm{~cm}$ ) di pertanaman, pada jarak 1, 3, 7, 10, dan $20 \mathrm{~m}$ dari titik pelepasan.

Untuk menentukan tingkat parasitisasi, dua hari setelah pelepasan dikumpulkan kutu putih sentinel masing-masing 10 ekor dari setiap bibit. Kutu beserta bibit singkong dibawa ke laboratorium dan ditunggu hingga imago parasitoid muncul. Tingkat parasitisasi ditentukan berdasarkan banyaknya imago parasitoid yang muncul dari 10 kutu putih sentinel. Penentuan tingkat parasitisasi juga dilakukan 2-3 bulan setelah pelepasan. Selain itu, kemampuan menetap dari parasitoid di lapangan ditentukan berdasarkan pengamatan keberadaan parasitoid pada awal musim kemarau tahun berikutnya.

Analisis Data. Persebaran kutu putih P. manihoti di Pulau Jawa dipetakan dengan bantuan program Arc GIS versi 10.41. Pengaruh perlakuan pelepasan A. lopezi terhadap tingkat parasitisasi diperiksa dengan sidik ragam, yang dilanjutkan dengan uji Tukey pada taraf nyata $5 \%$. Seluruh analisis data dilakukan melalui bantuan perangkat lunak SPSS 20.0.

\section{HASIL DAN PEMBAHASAN}

Persebaran dan Kondisi Serangan $P$. manihoti di Pulau Jawa. Hasil survei lapangan menunjukkan bahwa kutu $P$. manihoti ditemukan hampir di seluruh wilayah Pulau Jawa (Gambar 1). Dari 35 titik lokasi survei, kutu putih $P$. manihoti dijumpai pada pertanaman singkong di 22 lokasi yang tersebar di Jawa Barat (10 lokasi), Jawa Tengah (7 lokasi), dan Jawa Timur (5 lokasi). Sementara itu, gejala bekas serangan kutu putih, berupa pemendekan buku dan distorsi batang, dijumpai pada 13 lokasi lainnya.

Keberadaan P. manihoti pada tanaman singkong ditandai oleh adanya koloni kutu putih yang terdiri dari nimfa yang berwarna merah jambu serta imago dan ovisak yang berwarna putih seperti kapas, khususnya pada bagian pucuk tanaman singkong. Selain itu, tanaman yang terserang tampak daun-daun pucuknya mengeriting dan menggumpal (bunchytop), dan tidak berkembang normal. Bila pucuk tersebut dibuka, biasanya ditemukan kutu putih didalamnya. Rataan banyaknya kutu putih per pucuk berkisar antara 4,82 ekor (Kabupaten Pasurunan) hingga 45,10 ekor (Kabupaten Rembang). Pertanaman yang sebelumnya pernah terserang oleh $P$. manihoti dapat dikenali oleh adanya bagian-bagian buku yang memendek atau adanya distorsi pada batang.

Berdasarkan ketinggian tempat, kutu putih $P$. manihoti ditemukan pada pertanaman singkong pada rentang ketinggian $15 \mathrm{~m}$ dpl (Desa Kranjan, Kabupaten Pacitan) hingga 840 m dpl (Desa Semplak, Kabupaten Sukabumi). Tanaman singkong tersebut ada yang berupa tanaman pekarangan, tanaman pagar, tanaman

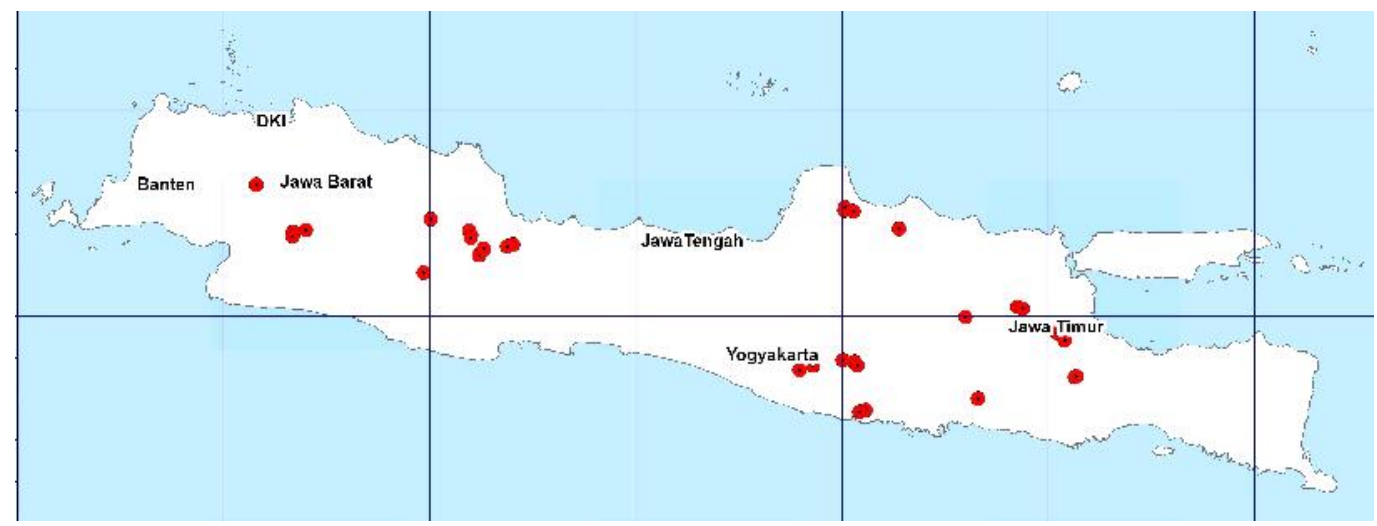

Gambar 1. Persebaran kutu putih P. manihoti di Pulau Jawa 
perkebunan, tanaman sisipan atau tumpangsari di lahan hutan.

Serangan yang tergolong sangat berat ditemukan pada pertanaman singkong, yang luasnya sekitar 20 ha, di daerah Borobamban dan sekitar Bandara Abdurachman Saleh Kecamatan Pakis Malang. Di tempat ini seluruh tanaman singkong tampak daunnya rontok dan sebagian tanaman mati dan mengering. Di daerah ini penanaman singkong dilakukan tidak serempak, yang ditunjukkan oleh umur tanaman yang tidak seragam. Pola tanam yang demikian diduga merupakan salah satu faktor yang menunjang peningkatan serangan pada musim kemarau. Selain itu, pertanaman singkong ini diusahakan di lahan tidur milik Bandara sehingga kurang mendapat perawatan. Dilaporkan bahwa serangan kutu putih $P$. manihoti lebih berat pada tanaman yang tumbuh di lahan yang miskin hara dan kurang pupuk (Le Ru et al., 1991 dalam Schulthess et al., 1997).

Situasi berbeda ditemukan di daerah Manyaran dan Karangmojo (Kabupaten Gunung Kidul) serta Jatisrono dan Ngadirejo (Kabupaten Wonogiri). Di tempat ini tidak ditemukan pertanaman singkong, karena seluruh lahan dalam keadaan bera menunggu musim hujan tiba. Di beberapa sudut lahan tampak kumpulan batang singkong terikat di atas lahan atau tergantung pada pohon nangka atau randu, yang dipersiapkan sebagai stek/bibit untuk musim tanam berikutnya. Pengamatan menunjukkan setiap tunas yang muncul dari batang-batang tersebut tampak berwarna putih karena penuh ditutupi oleh kutu P. manihoti. Diperkirakan kutu P. manihoti dapat menjadi hama penting di wilayah ini. Namun demikian, hasil wawancara dengan beberapa petani singkong menunjukkan bahwa keberadaan hama ini tidak terlalu dianggap penting dan menjadi masalah. Hal ini diduga karena petani menanam singkong pada awal musim hujan. Dengan cara ini, pada saat hama ini meningkat populasinya pada musim kemarau, tanaman singkong sudah berumur 6-7 bulan sehingga lebih toleran terhadap serangan $P$. manihoti. Menurut Nwanze (1982) pengaruh serangan kutu putih terhadap hasil panen singkong tergantung umur tanaman pada saat serangan terjadi. Wardani (2015) melaporkan bahwa kehilangan hasil lebih tinggi pada singkong yang pada saat masih muda terserang berat oleh kutu P. manihoti.

Salah satu daerah pengembangan singkong di Pulau Jawa adalah Kabupaten Pati. Di daerah ini terdapat pengembangan pertanaman singkong seluas 50 ha, yang direalisasikan melalui pembukaan lahan dan penyediaan bibit singkong. Secara keseluruhan untuk wilayah Kabupaten Pati pada tahun 2015 luas areal tanam singkong mencapai 18,259 ha dengan produktivitas
217,70 kuintal/ha dengan total produksi basah 397,498 ton (Pemkab Pati, 2015). Serangan P. manihoti di daerah ini tampak dari ditemukannya kutu putih dan pemendekan buku pada tanaman terserang. Pada beberapa kebun, insidensi serangan mencapai $100 \%$ dan sebagian tanaman yang terserang tampak mati mengering.

Selain kutu putih $P$. manihoti, selama pengamatan lapangan sering pula dijumpai kutu putih lainnya pada tanaman singkong yaitu Paracoccus marginatus, Ferrisia virgata dan Pseudococcus jackbeardsleyi. Kutu $P$. marginatus sangat umum dijumpai dan biasanya terdapat pada permukaan bawah daun, sedangkan $F$. virgata dan $P$. jackbeardsley biasanya menyerang tanaman yang tumbuh merana karena terserang $P$. manihoti.

Survei yang dilakukan dalam penelitian ini masih terbatas pada persebaran P. manihoti di Pulau Jawa. Kunjungan lapangan ke Lampung pada bulan Juni 2014 mendapatkan pertanaman singkong yang terserang berat P. manihoti (Rauf \& Wyckhuys komunikasi pribadi). Mengingat kutu putih singkong berpotensi menyebar ke pulau lainnya di seluruh Indonesia, kiranya perlu dilakukan survei secara nasional, terutama di sentra pengembangan singkong.

Tingkat Parasitisasi di dalam Kurungan. Perlakuan pelepasan parasitoid $A$. lopezi $i$ berpengaruh sangat nyata terhadap tingkat parasitisasi $(\mathrm{F}=129,7 ; \mathrm{db}=2,29 ; \mathrm{P}<$ 0,001). Pada perlakuan pelepasan 3 pasang A. lopezi rataan tingkat parasitisasi yaitu $25,20 \%$, lebih tinggi dibandingkan pada perlakuan pelepasan 1 pasang parasitoid $(17,60 \%)$. Adanya parasitoid yang muncul $(0,10 \%)$ dari perlakuan kontrol diduga karena adanya sejumlah kecil kutu putih yang terparasit pada saat perbanyakan massal di laboratorium (Gambar 2).

Pelepasan parasitoid berpengaruh terhadap laju kematian tanaman singkong. Pada kurungan tanpa parasitoid (kontrol), gejala kematian tanaman berlangsung lebih awal. Pada hari ke- 25 terjadi kematian tanaman sebanyak $10 \%$ dan meningkat menjadi $20 \%$ pada hari ke-45 (Gambar 3). Pada hari ke-60 seluruh tanaman singkong (100\%) menunjukkan gejala kematian. Kematian tanaman lebih rendah pada kurungan dengan pelepasan parasitoid. Pada kurungan dengan perlakuan 1 pasang A. lopezi kematian tanaman pada hari ke-60 adalah 50\%, sedangkan pada perlakuan pelepasan 3 pasang A. lopezi $20 \%$. Tampak pula bahwa pada perlakuan pelepasan parasitoid tidak terjadi kematian tanaman hingga hari ke-45. Tanaman yang mati tampak pucuknya mengering dan dipenuhi gumpalan kutu putih dan ovisak. 
Dalam percobaan ini, walaupun diinokulasi parasitoid, kematian tanaman masih tetap terjadi. Hal ini karena inokulasi hanya berlangsung selama dua hari, setelah itu tanaman dipindahkan ke kurungan lain. Pada keadaan parasitoid dibiarkan hidup dan berkembang biak di dalam kurungan, dipastikan tanaman yang mati sedikit atau bahkan tidak ada, terutama pada perlakuan 3 pasang parasitoid. Parasitoid A. lopezi merupakan musuh yang efisien karena, selain memarasit, juga memperlihatkan perilaku pengisapan inang (hostfeeding). Neuenschwander \& Sullivan (1987) melaporkan bahwa kematian kutu putih akibat pengisapan inang oleh A. lopezi sekitar 2-3 kali lipat daripada akibat diparasit. Kiranya percobaan inklusi ini

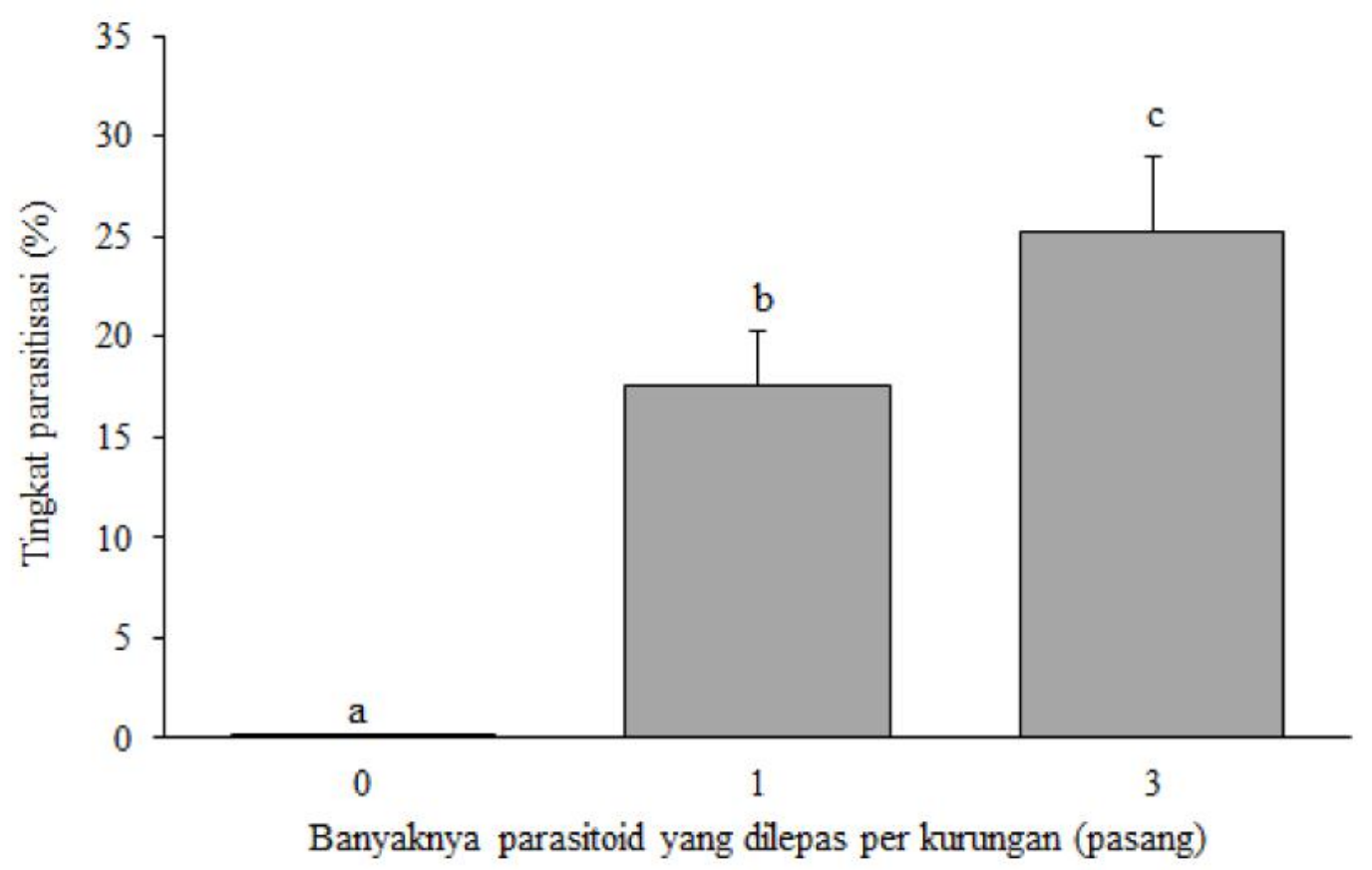

Gambar 2. Pengaruh banyaknya parasitoid yang dilepas terhadap tingkat parasitisasi

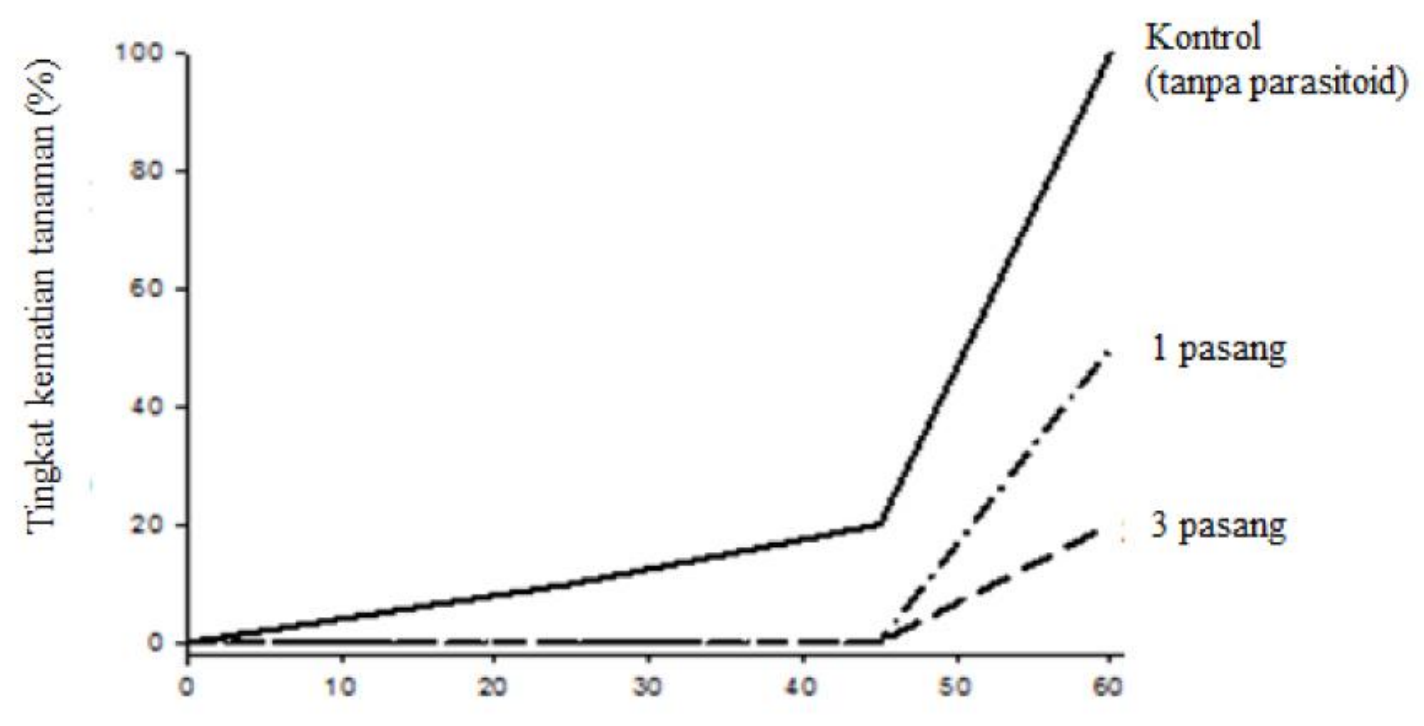

Hari setelah infestasi (hsi)

Gambar 3. Pengaruh keberadaan parasitoid terhadap laju kematian tanaman singkong oleh kutu putih 
perlu diulangi dengan membiarkan parasitoid A. lopezi hidup dan berkembang lebih lama di dalam kurungan, paling tidak satu generasi.

Tingkat Parasitisasi di Lapangan. Hasil pengamatan menunjukkan bahwa parasitoid yang dilepas berhasil memarasit kutu putih singkong di lapangan. Berdasarkan kutu putih yang dikumpulkan dua hari setelah pelepasan parasitoid, tampak bahwa jarak inang terhadap titik pelepasan berpengaruh nyata terhadap tingkat parasitisasi $(\mathrm{F}=6,77 ; \mathrm{db}=4,14 ; \mathrm{p}=0,007)$. Tingkat parasitisasi tertinggi (25\%) terjadi pada kutu putih yang berjarak $1 \mathrm{~m}$ dari titik pelepasan parasitoid. Tingkat parasitisasi menurun dengan makin jauhnya inang dari titik pelepasan seperti tampak pada jarak $20 \mathrm{~m}$ tingkat parasitisasi rata-rata 6,59\% (Gambar 4).

Bila pengambilan contoh kutu putih dilakukan pada selang waktu yang lebih lama sejak parasitoid dilepas, diperkirakan kutu putih yang terparasit dapat ditemukan pada jarak yang lebih jauh. Parasitoid A. lopezi dapat memencar secara aktif, terbawa melalui angin, atau terbawa melalui mumi yang menempel pada stek bibit. Di Afrika dilaporkan parasitoid A. lopezi mampu memencar dengan laju 50-100 km dalam satu musim kemarau (5-8 bulan) (Herren et al., 1987).

Kolonisasi dan Keberhasilan Menetap. Hasil pengamatan yang dilakukan beberapa bulan setelah pelepasan menunjukkan bahwa parasitoid A. lopezi berhasil berkembang biak di lapangan. Hal ini tampak dari rataan tingkat parasitisasi pada bulan kedua setelah pelepasan yang mencapai 37,67\%. Parasitisasi ini dipastikan dilakukan oleh keturunan (generasi-1) dari induk parasitoid yang dilepaskan. Hal ini mengingat siklus hidup A. lopezi berlangsung sekitar tiga minggu (Adriani, 2016). Pengamatan pada bulan ketiga setelah pelepasan mendapatkan rataan tingkat parasitisasi sekitar 22,67\%. Penurunan tingkat parasitisasi ini diduga berkaitan dengan mulai banyaknya turun hujan yang berpengaruh buruk terhadap kutu putih maupun parasitoid.

Pengamatan lapangan yang dilakukan pada awal Juni 2016, atau 9 bulan setelah pelepasan, mendapatkan imago parasitoid $A$. lopezi di sekitar koloni kutu putih $P$. manihoti. Hal ini merupakan indikasi awal bahwa parasitoid A. lopezi mampu menetap di lapangan melewati musim hujan, periode yang sangat tidak menguntungkan bagi kehidupan parasitoid, karena inang yang tersedia di lapangan sangat rendah. Keberhasilan pengendalian hayati $P$. manihoti oleh parasitoid $A$. lopezi di banyak negara di Afrika (Hammond et al., 1987) dan di Thailand (Jaipet, 2014) diharapkan dapat terulang di Indonesia. Untuk maksud tersebut, upaya pelepasan parasitoid A. lopezi di daerah yang terserang berat $P$. manihoti perlu segera dilakukan. Dalam kaitan ini, kiranya perlu dilakukan pelatihan pembiakan dan pelepasan parasitoid A. lopezi bagi petugas-petugas laboratorium pengendalian hayati yang ada di tiap kabupaten atau provinsi.

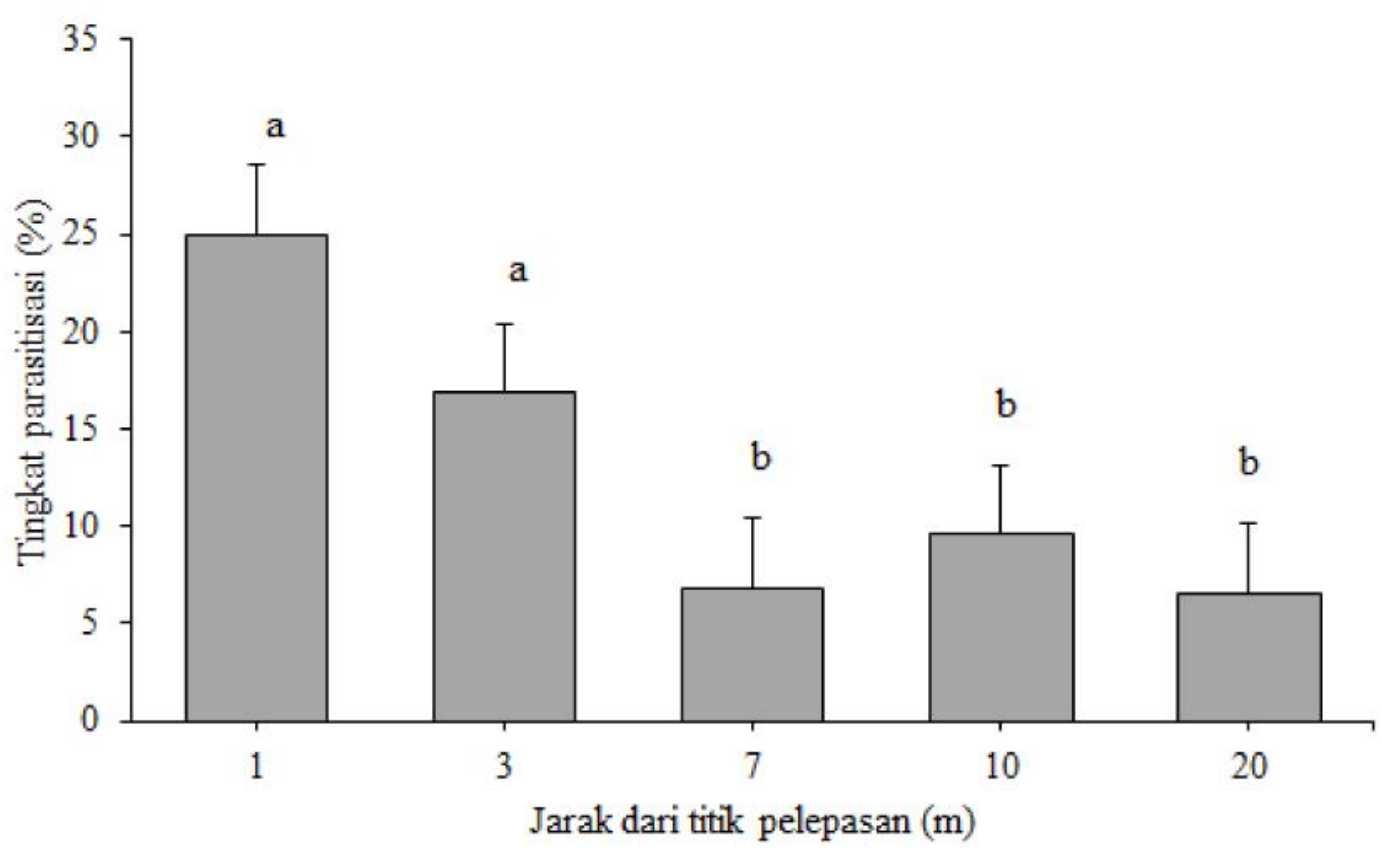

Gambar 4. Perbandingan tingkat parasitisasi pada berbagai jarak dari titik pelepasan parasitoid 


\section{SIMPULAN}

Kutu putih singkong $P$. manihoti telah tersebar luas di Pulau Jawa. Parasitoid A. lopezi yang dilepas mampu berkembang biak dan menetap di lapangan.

\section{SANWACANA}

Penelitian ini merupakan bagian dari tesis pada program Sekolah Pascasarjana Institut Pertanian Bogor tahun ajaran 2013-2014.

\section{DAFTAR PUSTAKA}

Adriani E. 2016. Preferensi, kesesuaian dan parasitisme Anagyrus lopezi De Santis (Hymenoptera: Encyrtidae) padaberbagai instarkutu putih singkong Phenacoccus manihoti Matile-Ferrero(Hemiptera: Pseudococcidae). [Tesis]. Institut Pertanian Bogor. Bogor.

FAO. 2011. Report of Capacity Building for Spread Prevention and Management of Cassava Pink Mealybug in the Greater Mekong Subregion. In: FAO Report. pp. 56. Bangkok.

Hammond WNO, Neuenschwander P, \& Herren HR. 1987. Impact of the exotic parasitoid Epidinocarsis lopezi on cassava mealybug (Phenacoccus manihoti) populations. Recent Advances in Research on Tropical Entomology. 8(4/5/6): 887-891.

Heng-Moss TM, Baxendale FP, Riordan TP, \& Young LJ. 1999. Influence of Rhopus nigroclavatus (Hymenoptera: Encyrtidae) on the mealybugs Tridiscus sporoboli and Trionymus sp. (Homoptera: Pseudococcidae). Environ Entomol. 28(1): 123-127.

Herren HR \& Lema KM. 1982. CMB-first successful releases. Biocontrol News and Info. 3:185.

Herren HR \& Neuenschwander RP. 1991. Biological control of cassava pests in Africa. Annu. Rev. Entomol. 36: 257-283.

Herren HR, Neuenschwander P, Hennessey RD, \& Hammond WNO. 1987. Introduction and dispersal of Epidinocarsis lopezi (Hym., Encyrtidae), an exotic parasitoid of the cassava mealybug, Phenacoccus manihoti (Hom., Pseudococcidae), in Africa. Agr. Ecosys. Environ. 19(2): 131-144.
Jaipet A. 2014. Thailand experiences in mass rearing parasitoid. In: CIAT-IPB Seminar on invasive mealybugs. Bogor September 24, 2014.

Karyani RD. 2015. Pengujian kesesuaian inang parasitoid Anagyrus lopezi De Santis (Hymenoptera: Encyrtidae) terhadap kutu putih yang berasosiasi dengan ubi kayu (Manihot esculenta Crantz) [Tesis] . Institut Pertanian Bogor. Bogor.

Kiritani K \& Dempster JP. 1973. Different approach to the quantitative evaluation of natural enemies. $J$ Appl. Ecol. 10: 323-330.

Lefroy D. 2010. Cassava under threat: Pest nand disease outbreaks put SE Asia on high alert. CIAT E-Newsletter No. 6. Tersedia pada: http:// cgspase.cgiar.org. Diakses tanggal 1 Agustus 2016.

Muniappan R, Shepard BM, Watson GW, Carner GR, Rauf A, Sartiami D, Hidayat P, Afun JVK, Goergen G, \& Ziaur Rahman AKM. 2009. New records of invasive insects (Hemiptera: Sternorrhyncha) in Southeast Asia and West Africa. J Agr. Urban Entomol. 26(4): 167-174.

Neuenschwander P. 1994. Control of the cassava mealybug in Africa: lessons from a biological control project. Afr. Cro. Sci. J. 2(4): 369-383.

Neuenschwander P \& Sullivan D. 1987. Interactions between the endophagous parasitoid Epidinocarsis lopezi and its host, Phenacoccus manihoti. Int. J. Insect. Sci. 8(4/5/6): 857-859.

Norgaard RB. 1988. The biological control of cassava mealybug in Africa. Am. J. Agr. Econ. 70(2): 366371.

Nwanze KF. 1982. Relationships between cassava root yields and crop infestations by the mealybug, Phenacoccus manihoti. Trop. Pest Manage. 28(1): 27-32.

Nwanze KF, Leuschner K, \& Ezumah HC. 1979. The cassava mealybug, Phenacoccus sp. in the Republic of Zaire. PANS 25(2): 125-130.

Parsa S, Kondo T, \& Winotai A. 2012. The cassava mealybug (Phenacoccus manihoti) in Asia: first records, potential distribution, and an identification key. PLOS ONE 7(10): e47675.

Pemkab Pati. 2015. Profil Kabupaten Pati. Tersedia pada: http://www.jatengprov.go.id/id/profil/kabupatenpati. Diakses tanggal 25 Desember 2015. 
Rauf A. 2014. Invasi kutu putih Phenacoccus manihoti. Di dalam: Seminar Kutu putih vs Parasitoid: Pengelolaan hama asing invasifberbasis ekologi. Bogor 24 Sep 2014.

Schulthess F, Neuenschwander P, \& Gounou S. 1997. Multi-tropic interactions in cassava, Manihot esculenta, cropping systems in the subhumid tropics of West Africa. Agr. Ecosyst. Environ. 66: 211-222.

Simmons GS \& Minkenberg OPJM. 1994. Field cage evaluation of augmentative biological control of Bemisia argentifolii (Homoptera: Aleyrodidae) in Southern California cotton with parasitoid Eretmocerus $n r$. californicus (Hymenoptera: Aphelinidae). Environ Entomol. 23(6): 15521557.
Suherman M. 2014. Kebijakan pengembangan singkong di Indonesia. Di dalam: Seminar Kutu putih vs Parasitoid: Pengelolaan hama asing invasif berbasis ekologi. Bogor 24 September 2014.

Wardani N. 2015. Kutu putih ubi kayu Phenacoccus manihoti Matile-Ferrero (Hemiptera: Pseudococcidae), hama invasif baru di Indonesia [Disertasi]. Institut Pertanian Bogor. Bogor.

Wyckhuys KAG, Rauf A, \& Ketelaar J. 2014. Parasitoid introduced into Indonesia: part of a region-wide campaign to tackle emerging cassava pests and diseases. Biocontrol News and Inform. 35(4):3537. 